\title{
Changes in geometry and subglacial drainage derived from digital elevation models: Unteraargletscher, Switzerland, 1927-97
}

\author{
Urs H. FISCHER, ${ }^{1 *}$ André BRAUN, ${ }^{1}$ Andreas BAUDER, ${ }^{1}$ Gwenn E. FLOWERS ${ }^{2}$ \\ ${ }^{1}$ Laboratory of Hydraulics, Hydrology and Glaciology, ETH-Zentrum, CH-8092 Zürich, Switzerland \\ Email: urs.fischer@utas.edu.au \\ ${ }^{2}$ Department of Earth and Ocean Sciences, University of British Columbia, Vancouver, British Columbia V6T 1Z4, Canada
}

\begin{abstract}
Digital elevation models of the bed and surface of Unteraargletscher, Switzerland, are used to reconstruct the theoretical pattern of basal water drainage for the years 1927, 1947, 1961 and 1997, during which period the glacier was thinning and receding. The theoretical drainage pattern for 1997 compares well, in a broad sense, with the locations of active moulins and the hydraulic connection status of boreholes drilled to the glacier bed. Changes in the basal water-flow pattern over the period 1927-97 that are revealed by the theoretical reconstructions of the subglacial drainage system structure are likely to have resulted from changes in glacier geometry. Concurrent with the retreat and thinning of the glacier, the height of medial moraines increased, probably due to the insulating effect of the debris cover reducing the melt of the underlying ice. This increase of moraine heights has led to the formation of hydraulic barriers at the glacier bed such that water flow has become channelized beneath the ice along drainage axes that parallel the course of the medial moraines on the glacier surface.
\end{abstract}

\section{INTRODUCTION}

Changes in glacier geometry and subglacial water drainage not only influence glacier dynamics (e.g. Bindschadler and others, 1977; Iken and Truffer, 1997) but also have implications for glacier mass balance and runoff from glaciated regions (e.g. Barrett and Collins, 1997; Braun and others, 2000). While much of the knowledge of the geometry and hydrology of glaciers and their changes with time has been gained from in situ measurements (e.g. Clarke and Blake, 1991; Fountain, 1993; Nienow and others, 1998), such fieldbased studies are difficult, time-consuming and expensive. As an alternative, remote sensing and terrain analysis techniques provide the basic data for assessing the geometry of glaciers and for studies of glacier hydrology. Changes in glacier thickness and extent have been determined from the analysis of sequential digital elevation models (DEMs) of the surface topography in combination with a DEM of the bed topography (e.g. Fountain and Vaughn, 1995; Hagen and others, 2000; Rippin and others, 2003). In addition, by calculating hydraulic potential surfaces across glacier beds, these DEMs have been used to identify the likely patterns of subglacial water flow and their changes with time (e.g. Sharp and others, 1993; Fountain and Vaughn, 1995; Flowers and Clarke, 1999; Hagen and others, 2000; Rippin and others, 2003).

In this paper, we use DEMs of the bed and surface of Unteraargletscher, Switzerland, to investigate changes in glacier geometry and subglacial drainage system structure between 1927 and 1997. To substantiate the reconstructed patterns of basal water flow, we compare the theoretical drainage network for 1997 with observations of the locations of active moulins and the hydraulic connection status of boreholes drilled to the glacier bed.

\footnotetext{
* Present address: Antarctic Climate and Ecosystems Cooperative Research Centre and Australian Antarctic Division, GPO Box 252-80, Hobart, Tasmania 7001, Australia
}

\section{STUDY AREA}

Unteraargletscher is a temperate valley glacier, situated in the Bernese Alps, Switzerland, emanating from the confluence of two main tributaries, Finsteraar- and Lauteraargletscher (Fig. 1). Since 1924, systematic measurements of changes in surface elevation and displacement have been carried out on Unteraargletscher every year (Flotron, 19242003). More recently, the main emphasis of research activities has been extensive investigations of glacier hydrology and dynamics (e.g. Iken and others, 1983; Funk and Röthlisberger, 1989; Gudmundsson and others, 1997, 1999, 2000; Fischer and others, 2001; Schuler and others, 2002, 2004; Schuler and Fischer, 2003).

Unteraargletscher is $\sim 6 \mathrm{~km}$ long, $1 \mathrm{~km}$ wide and has a mean surface slope of approximately $4^{\circ}$. A prominent feature of the glacier is the large ice-cored medial moraine which is formed by the convergence of the lateral moraines of Lauteraar- and Finsteraargletscher. The debris cover of the moraine is typically $5-15 \mathrm{~cm}$ thick. At the confluence zone the medial moraine is $10-20 \mathrm{~m}$ high and $\sim 100 \mathrm{~m}$ wide. With distance down-glacier it grows to a maximum height of $50 \mathrm{~m}$ and width of $300 \mathrm{~m}$ before it gradually spreads out and merges with the marginal morainic debris in the terminus region. Smaller medial moraines on the southern side of Unteraargletscher are the result of Finsteraargletscher being fed by Strahlegggletscher and a number of smaller tributaries. In contrast, there are no tributaries that feed large amounts of ice to Lauteraargletscher, so the northern side of Unteraargletscher is nearly debris-free (Fig. 1).

\section{METHODOLOGY}

Shreve (1972) suggested that water moves in and under glaciers in response to hydraulic potential gradients. The total hydraulic potential at the base of a glacier, $\phi_{\mathrm{b}}$, is the sum of pressure potential and elevation potential,

$$
\phi_{\mathrm{b}}=P_{\mathrm{w}}+\rho_{\mathrm{w}} g z_{\mathrm{b}},
$$

where $P_{\mathrm{w}}=k \rho_{\mathrm{i}} g\left(z_{\mathrm{s}}-z_{\mathrm{b}}\right)$ is the subglacial water pressure, 


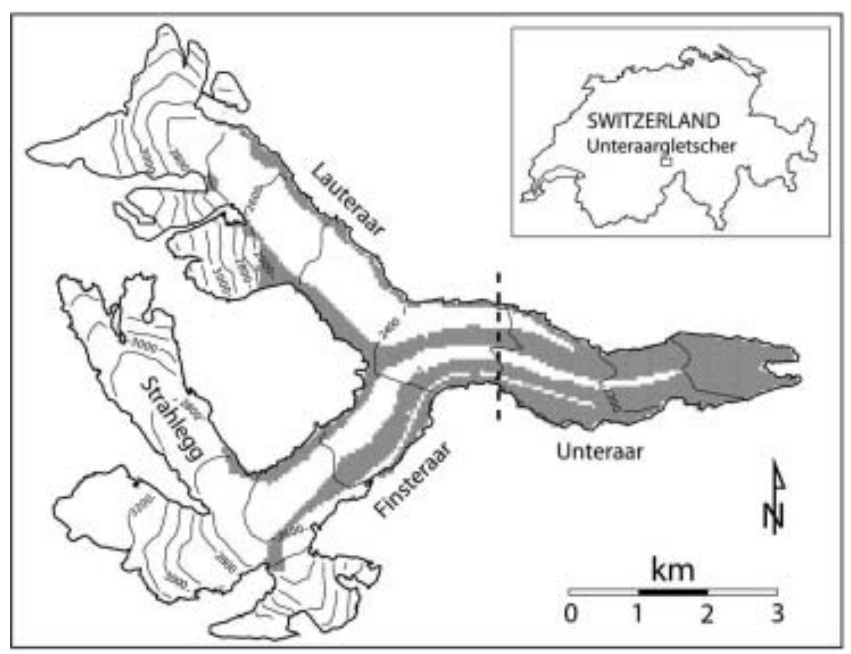

Fig. 1. Map of Unteraargletscher and its two main tributaries, Finsteraar- and Lauteraargletscher. The dashed line indicates the location of cross-sectional profiles shown in Figure 4 (see text for details). Shading on glacier represents debris-covered ice. Inset shows the study area in the Bernese Alps.

$\rho_{\mathrm{w}}$ and $\rho_{\mathrm{i}}$ are the densities of water and ice respectively, $g$ is the acceleration due to gravity, $z_{b}$ is the elevation of the glacier bed, $z_{\mathrm{S}}$ is the elevation of the ice surface and $k$ is a factor between 0 and 1 representing the range of the subglacial water pressure from atmospheric pressure $(k=0)$ to full ice-overburden pressure $(k=1)$.

Application of Equation (1) requires knowledge of the basal and surface topography of the glacier. The bed topography of Unteraargletscher is available from Funk and others (1994) and Bauder and others (2003), who determined the thickness of the ice by radio-echo sounding. To date, 12 DEMs of the glacier surface, either digitized from topographic maps or derived photogrammetrically from aerial photographs, are available from Bauder (2001) and include the years 1927,1947, 1961 and 1997. The DEMs of the bed and surface were embedded within the Swiss 1:25000 digital elevation model DHM25 of the entire catchment area $(\mathrm{L}+\mathrm{T}, 1993)$ and subsequently interpolated onto matching $20 \times 20 \mathrm{~m}$ grids (Braun, 2003). These DEMs were used as input to Equation (1) to calculate gridded values of subglacial hydraulic potential, with $\rho_{\mathrm{w}}=1000 \mathrm{~kg} \mathrm{~m}^{-3}, \rho_{\mathrm{i}}=917 \mathrm{~kg} \mathrm{~m}^{-3}$, $g=9.81 \mathrm{~m} \mathrm{~s}^{-1}$ and a spatially uniform factor $k$. We considered two steady-state subglacial water-pressure conditions, which can be regarded as characteristic limits of typical pressure variations in the drainage system beneath a temperate glacier: $k=1$, i.e. the water pressure is equal to the ice-overburden pressure in a hydraulically inefficient drainage system in winter, and $k=0.5$, i.e. the water pressure may drop below the ice-overburden pressure in summer as a consequence of diurnally varying surface meltwater input and the development and enlargement of drainage channels. While the channels themselves may operate at low pressures $(k \ll 1)$, the channelized drainage system occupies a small fraction of the bed and draws water out of a spatially extensive distributed system at high pressure. Measurements during the summer at Unteraargletscher in boreholes that are connected to the subglacial drainage system typically indicate subglacial water pressures that are $\geq 50 \%$ of the ice-overburden pressure (e.g. Fischer and others, 2001; Schuler and others, 2002).

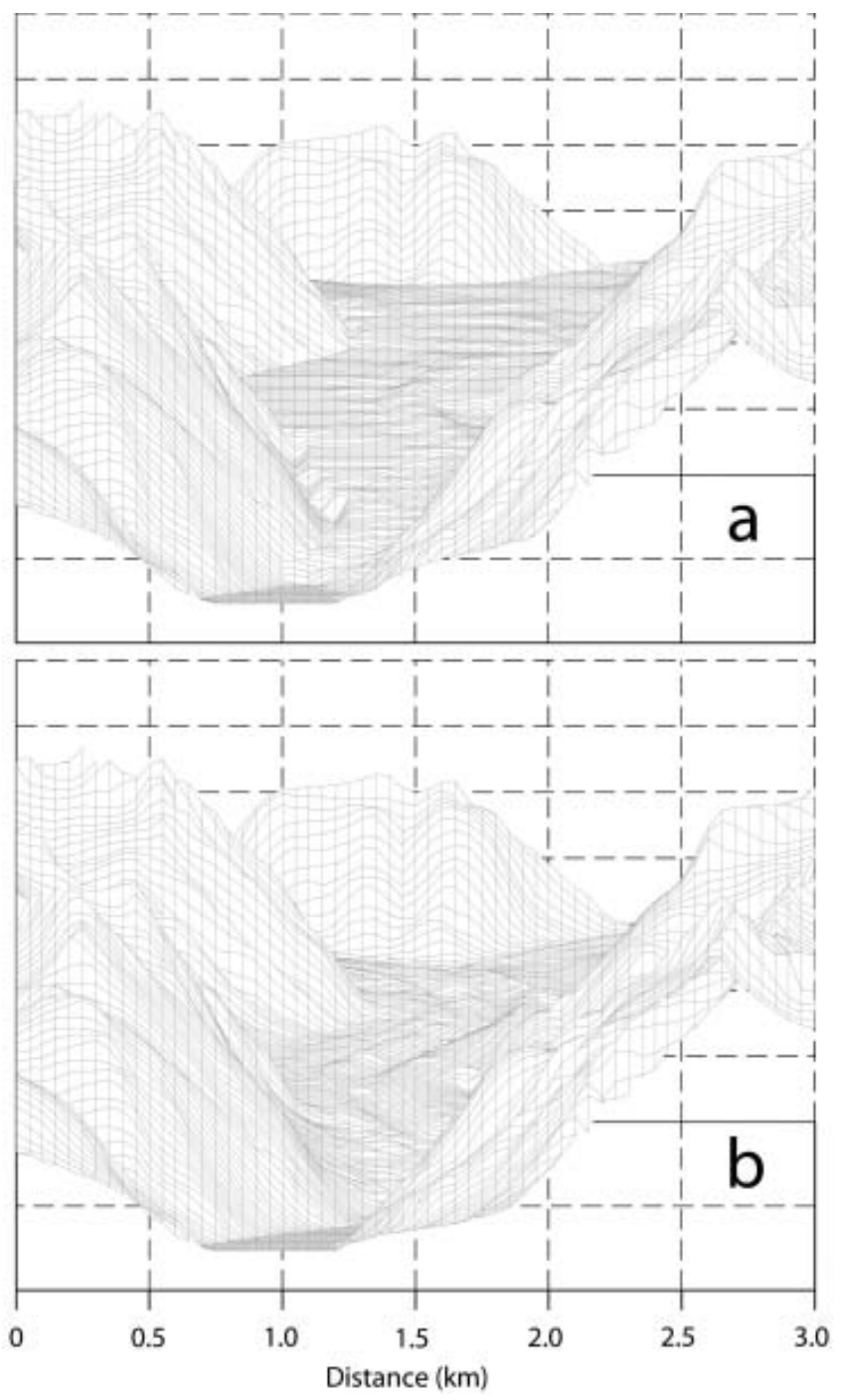

Fig. 2. DEMs of (a) the glacier surface in 1927, digitized from topographic maps (Bauder, 2001), and (b) the glacier surface in 1997, derived photogrammetrically from aerial photographs (Bauder, 2001). View is in up-glacier direction; north points to the right.

Using methods equivalent to that of Zevenbergen and Thorne (1987), we reconstructed theoretical patterns of the subglacial drainage network by computing upstream area distributions for each of the hydraulic potential surfaces. The procedure employs the 'multiple direction' algorithm (Quinn and others, 1991) numerically implemented by Flowers and Clarke (1999) and is briefly summarized as follows: for a particular gridcell, upstream area is computed as its own area plus the sum of all gridcell areas that are upstream and connected. Here, we define 'upstream' in terms of hydraulic potential. Furthermore, each gridcell transfers its upstream area to all downstream neighbours among the eight nearest in proportions determined by the relative magnitudes of the potential gradients. The resultant maps of upstream area distribution act as guides to the likely locations of preferential drainage paths.

\section{RESULTS}

\section{Glacier geometry}

The glacier bed of Unteraargletscher is U-shaped in the transverse direction and is only weakly inclined 

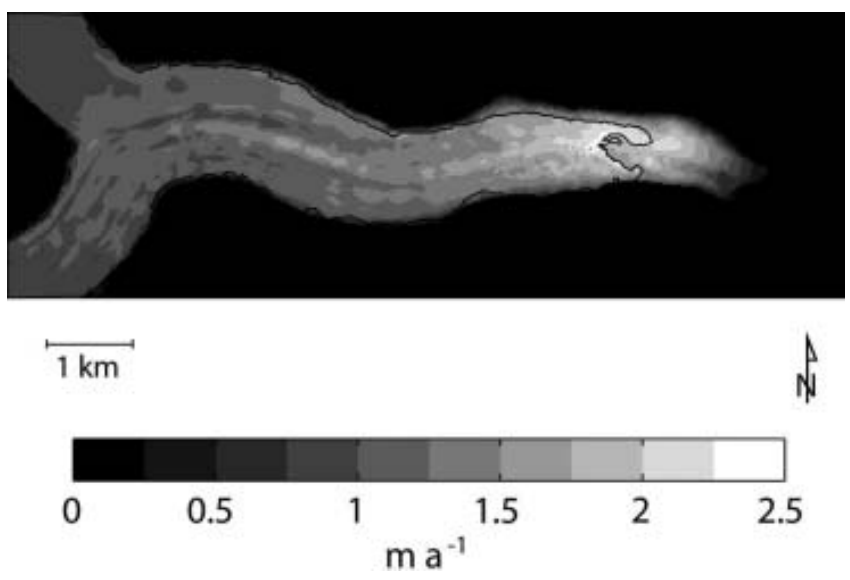

Fig. 3. Mean annual decrease in surface elevation, 1927-97. Black line shows the 1997 glacier boundary.

down-glacier from the confluence zone. Subtracting the 1927 surface DEM (Fig. 2a) from the 1997 surface DEM (Fig. 2b) displays the long-term surface elevation change (Fig. 3). All of Unteraargletscher underwent surface lowering in this period. Maximum glacier thinning occurred in the terminus region with a mean lowering rate of $\sim 2.5 \mathrm{~m} \mathrm{a}^{-1}$. Over the same 70 year period, the glacier snout retreated by roughly $1343 \mathrm{~m}$, corresponding to a mean retreat rate of $\sim 19 \mathrm{~m} \mathrm{a}^{-1}$.

Comparison of Figure $2 \mathrm{a}$ and $\mathrm{b}$ also reveals considerable small-scale changes in surface topography of the glacier. In 1927, only the medial moraine which originates from the confluence of Lauteraar- and Finsteraargletscher is clearly discernible. By 1997, this moraine has become more pronounced by increasing its height. In addition, smaller medial moraines have formed on the southern side of Unteraargletscher and on Finsteraargletscher. Cross-sectional profiles through the glacier in 1927, 1947, 1961 and 1997 (Fig. 4) approximately $1.5 \mathrm{~km}$ down-glacier from the confluence zone (Fig. 1) indicate that this height increase of the moraines has taken place gradually, concurrent with the retreat and thinning of the glacier. The reason for the height increase is likely a lower melt rate due to the debris cover that insulates the ice below. This notion is supported by the reduced glacier thinning observed in regions that coincide with the locations of the moraines (Fig. 3) and by reduced ablation rates measured on debris-covered ice (Bauder, 2001; Schuler and others, 2002).

\section{Subglacial drainage}

Figure 5 shows the hydraulic potential surfaces at the bed of the glacier for 1927 and 1997 computed using $k=1$. Water moves perpendicular to equipotential lines (Shreve, 1972), and water channelization at the bed is indicated in areas where contours are diverted to the west. In 1927 (Fig. 5a), two valleys on the potential surface that emerge from Finsteraar- and Lauteraargletscher can be traced along the southern and, somewhat less distinct, northern side of Unteraargletscher, respectively. The distribution of hydraulic potential in 1997 displays a greater structure (Fig. 5b), and potential lows are better defined than in 1927. In addition to the two potential valleys along the southern and northern side of Unteraargletscher, a third valley follows the glacier centre line all the way to the terminus.

Upstream area distributions for 1927, 1947, 1961 and 1997 computed using $k=1$ are shown in Figure 6. Bright

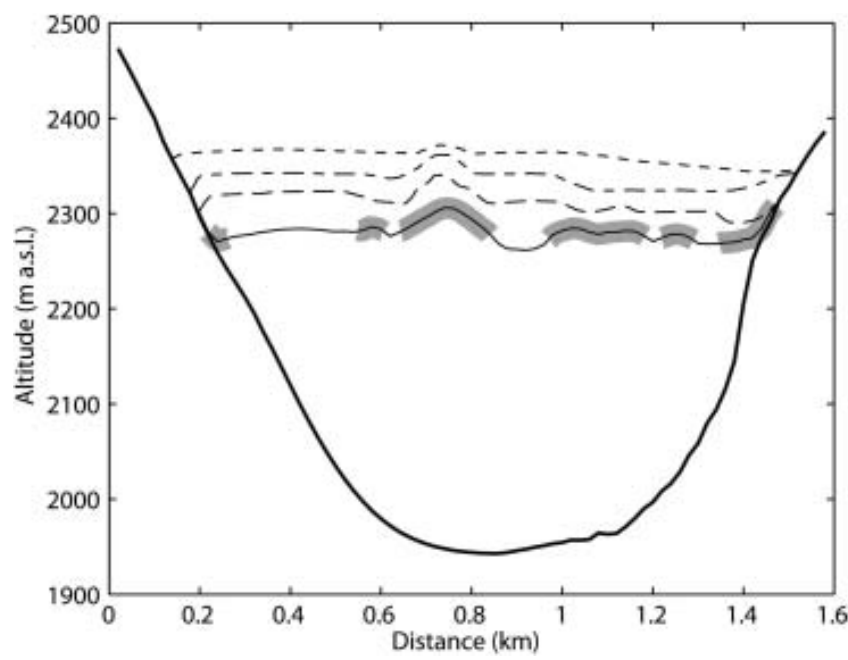

Fig. 4. Cross-sectional profiles through Unteraargletscher in 1927 (dotted line), 1947 (dash-dotted line), 1961 (dashed line) and 1997 (solid line) at the location shown in Figure 1. Note the increase in height of the medial moraines concurrent with the thinning of the glacier. Thick grey lines indicate debris-covered ice in 1997. Glacier flow is into the page; north points to the left.

areas (high values of upstream area) indicate regions at the bed that are hydraulically favourable for water flow. In contrast, dark areas (low values of upstream area) are hydraulically resistive. Where upstream area is not transferred to neighbouring gridcells, water flow is restricted and ponding may occur. These 'dead ends' in flow routing result from gridcells that are lower in hydraulic potential than all cells adjacent to them. In 1927 (Fig. 6a), major water-flow paths are predicted to follow the main valley axes beneath both Finsteraar- and Lauteraargletscher. Down-glacier from the confluence zone, the two flow paths join and bifurcate (similar to an anabranching network) and continue as two main drainage routes beneath Unteraargletscher. While the southerly of these extends all the way to the terminus, the other exits the glacier about $2 \mathrm{~km}$ up-glacier from the snout and subsequently follows the northern glacier margin.

The drainage pattern in 1947 (Fig. 6b) is largely similar to that in 1927. In 1961 (Fig. 6c), major changes are noticeable. While the water-flow path at the bed of Lauteraargletscher remains prominent, that beneath Finsteraargletscher is discontinuous, with major breaks, presumably reflecting a region of shallow hydraulic potential gradients where drainage is likely to be dispersed. In contrast, drainage beneath the southern side of Unteraargletscher tends to be channelized into several discrete routes. Water channelization at the bed is even more pronounced in 1997 (Fig. 6d). Beneath both Finsteraargletscher and the southern side of Unteraargletscher, water flow is strongly confined to a number of narrow drainage axes. Furthermore, the drainage route that collects much of its water from Lauteraargletscher and the northern side of Unteraargletscher emerges at the glacier margin $\sim 1.5 \mathrm{~km}$ further up-glacier from its exit location in 1927.

\section{Comparison with observations}

The black dots in Figure $6 \mathrm{~d}$ mark the locations of active moulins surveyed and mapped in 2002 (Braun, 2003). The moulins tend to be clustered along the lines of major waterflow paths predicted from the 1997 potential surface. This 

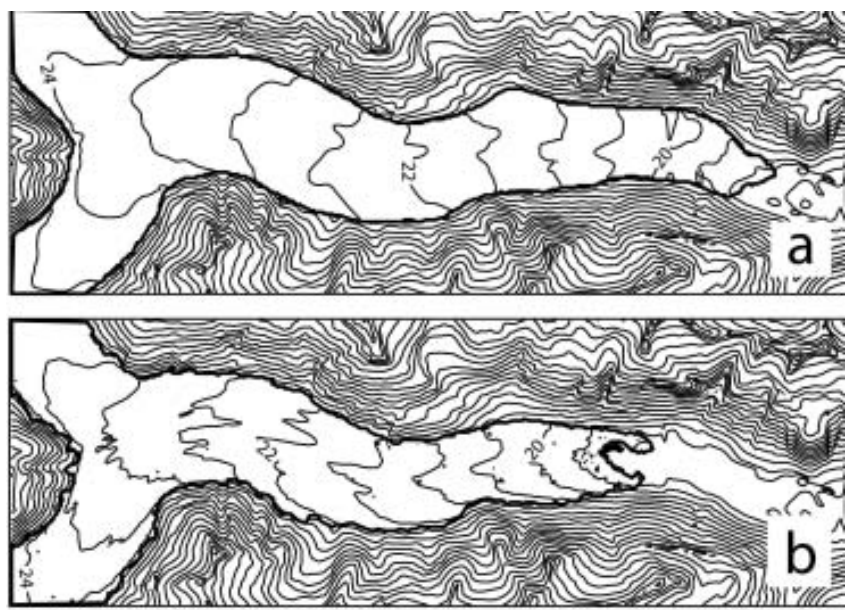

$1 \mathrm{~km}$ contours in $\mathrm{MPa}$

Fig. 5. Contours of equal hydraulic potential computed using $k=1$ in (a) 1927 and (b) 1997.

finding substantiates the results of our reconstructions of subglacial drainage networks given the dominant effect of surface slope on the hydraulic potential (especially for $k=1$; see Equation (1)), which implies that the location of longitudinal depressions on the glacier surface correlates closely with the location of valleys on the potential surface, and thus that surface meltwater channels tend to lie above subglacial drainage routes (Sharp and others, 1993). The implicit assumption that surface water reaches the glacier bed close to the moulins is reasonable because of the closure of moulins transported by ice flow away from the surface and subglacial drainage systems.

Support for the theoretical reconstructions of the subglacial drainage pattern also stems from a comparison of predicted water-flow paths with the connection status of boreholes drilled to the glacier bed (whether the water in the holes is in hydraulic communication with the subglacial drainage system). Of the fourteen holes drilled in 1999 and 2000 , seven were connected to the subglacial water system. We find good agreement between the locations of these boreholes and major drainage routes reconstructed for the 1997 potential surface. In contrast, the remaining unconnected holes are located in areas through which generally little water flow is predicted to be routed.

\section{Changes in subglacial drainage structure}

Long-term changes in the subglacial drainage pattern over the period 1927-97 (Fig. 6) are likely to have occurred as a result of changes in glacier geometry. Apart from the retreat of the front and lowering of the surface (Fig. 3), the biggest change in surface topography is the increase in height of the medial moraines (Fig. 4). Thus, while the ice-overburden pressure has generally decreased between 1927 and 1997 as the glacier has thinned, the increased variation in ice thickness due to differential ablation rates on debris-covered vs clean ice has led to locally increased pressure gradients in these regions. These gradients have formed new hydraulic barriers at the glacier bed (Fig. 5b), such that water is preferentially routed beneath the ice along drainage axes that parallel the course of the medial moraines on the glacier surface (Fig. 6d).
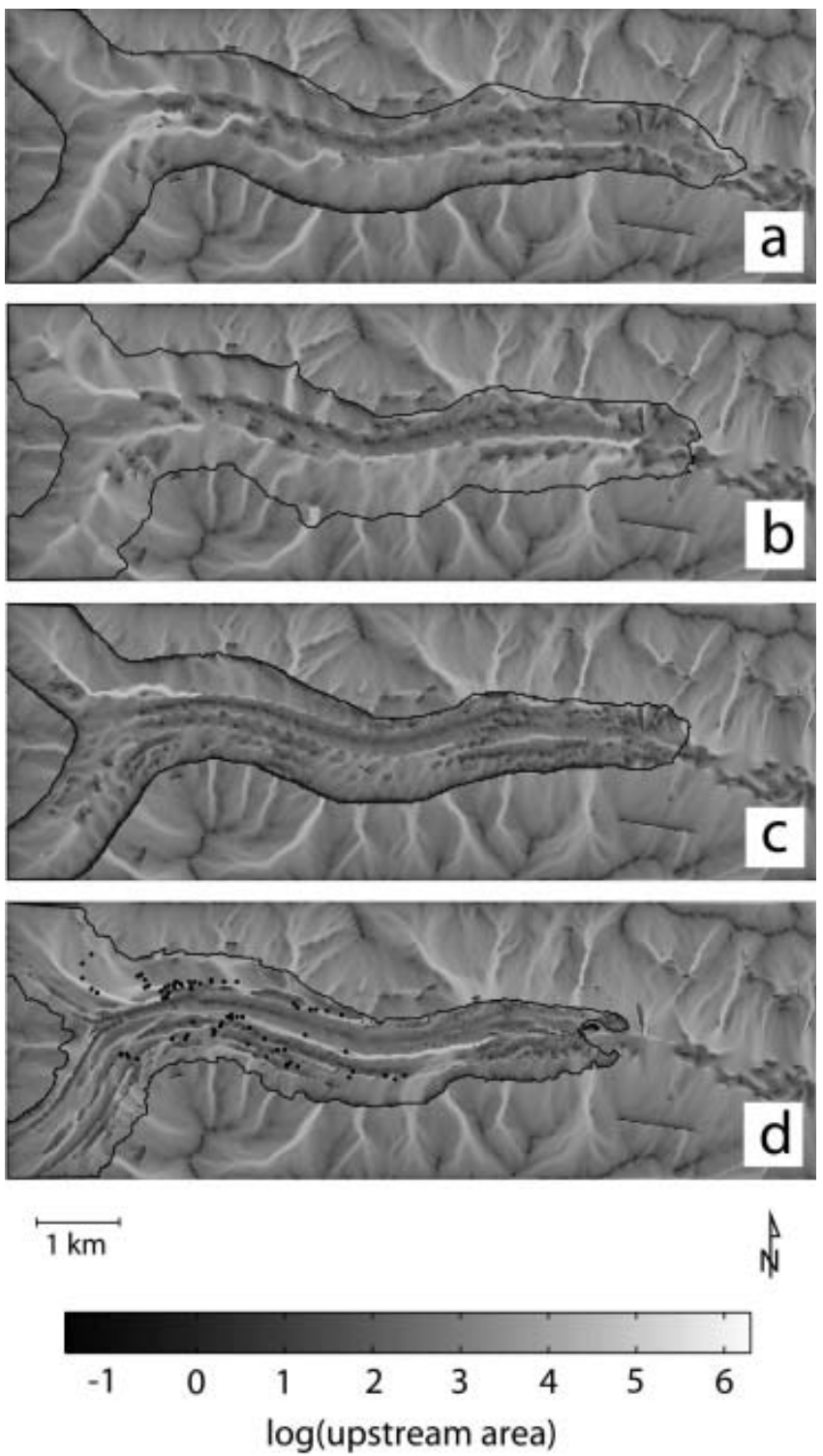

Fig. 6. Upstream area distributions computed using $k=1$ in (a) 1927, (b) 1947, (c) 1961 and (d) 1997. The black dots in (d) mark the locations of active moulins surveyed and mapped in 2002 (Braun, 2003).

\section{CONCLUDING DISCUSSION}

We have used DEMs and terrain analysis techniques to study the changes in geometry and subglacial drainage system structure of Unteraargletscher between 1927 and 1997. Concurrent with the retreat and thinning of the glacier during this period, differential ablation rates on debris-covered vs clean ice have led to an increasing prominence of medial moraines, which in turn has resulted in the formation of subglacial hydraulic barriers and increased channelization of water flow into discrete drainage routes beneath the ice.

In calculating the hydraulic potential surfaces and upstream area distributions shown in Figures 5 and 6, the subglacial water pressure was assumed to be equal to the ice-overburden pressure (i.e. $k=1$ ). We found that reconstructions of the subglacial drainage pattern using $k=0.5$, reflecting a greater influence of bed topography on the hydraulic potential (see Equation (1)), made no significant difference to the suggested water-flow routing at the glacier bed. Thus, our conclusions regarding the formation of 
subglacial drainage barriers due to the increasing prominence of medial moraines are robust to uncertainty in the value of $k$ within realistic bounds of typical water pressures beneath a temperate glacier.

Errors in elevation of the bed and glacier surfaces were estimated by Bauder (2001) to be \pm 10 and $\pm 5 \mathrm{~m}$, respectively. These errors imply that the ice thickness may be overestimated or underestimated by up to $15 \mathrm{~m}$. Because errors associated with determining the elevation of the basal and surface topography of a glacier are likely to be systematic, we investigated the effect of these elevation errors on the reconstructed pattern of the subglacial drainage network by computing hydraulic potential surfaces and upstream area distributions for the thickest possible and thinnest possible glacier. In all cases, there were no discernible differences between the results of these computations and those presented in Figures 5 and 6 .

Our analysis does not account for variations in subglacial water pressure due to variations in the water discharge and drainage morphology. Hence, changes in subglacial drainage pattern only occur when the glacier geometry changes as the glacier retreats and thins. A more accurate reconstruction of subglacial water-flow routing would require a model that includes subglacial physics.

\section{ACKNOWLEDGEMENTS}

This study was partially funded by the Swiss Federal Institute of Technology (ETH grant TH-7/01-1). Fieldwork was carried out with much help from A. Brack, T. Schuler, M. Rousselot and many others associated with the research programme on Unteraargletscher. We thank A. Pralong for his help with computing-related questions and W.T. Pfeffer, M.J. Sharp and A.P. Ahlstrøm for constructive comments on the manuscript.

\section{REFERENCES}

Barrett, A.P. and D.N. Collins. 1997. Interaction between water pressure in the basal drainage system and discharge from an Alpine glacier before and during a rainfall-induced subglacial hydrological event. Ann. Glaciol., 24, 288-292.

Bauder, A. 2001. Bestimmung der Massenbilanz von Gletschern mit Fernerkundungsmethoden und Fliessmodellierungen. (PhD thesis, Eidgenössische Technische Hochschule.)

Bauder, A., M. Funk and G.H. Gudmundsson. 2003. The icethickness distribution of Unteraargletscher, Switzerland. Ann. Glaciol., 37, 331-336.

Bindschadler, R., W.D. Harrison, C.F. Raymond and R. Crosson. 1977. Geometry and dynamics of a surge-type glacier. J. Glaciol., 18(79), 181-194.

Braun, A. 2003. Veränderungen der Geometrie und der subglazialen Abflussstruktur des Unteraargletschers. (Diploma thesis, Eidgenössische Technische Hochschule.)

Braun, L.N., M. Weber and M. Schulz. 2000. Consequences of climate change for runoff from Alpine regions. Ann. Glaciol., 31, 19-25.

Clarke, G.K.C. and E.W. Blake. 1991. Geometric and thermal evolution of a surge-type glacier in its quiescent state: Trapridge Glacier, Yukon Territory, Canada, 1969-89. J. Glaciol., 37(125), 158-169.

Fischer, U.H., P.R. Porter, T. Schuler, A.J. Evans and G.H. Gudmundsson. 2001. Hydraulic and mechanical properties of glacial sediments beneath Unteraargletscher, Switzerland: implications for glacier basal motion. Hydrol. Process., 15(18), 3525-3540.

Flotron, A. 1924-2003. Jährliche Berichte über die Ergebnisse der Gletschermessungen in Auftrag der Kraftwerke Oberhasli. Annual Reports.
Flowers, G.E. and G.K.C. Clarke. 1999. Surface and bed topography of Trapridge Glacier, Yukon Territory, Canada: digital elevation models and derived hydraulic geometry. J. Glaciol., 45(149), 165-174.

Fountain, A.G. 1993. Geometry and flow conditions of subglacial water at South Cascade Glacier, Washington State, USA: an analysis of tracer injections. J. Glaciol., 39(131), 143-156.

Fountain, A.G. and B.H. Vaughn. 1995. Changing drainage patterns within South Cascade Glacier, Washington, USA, 1964-1992. International Association of Hydrological Sciences Publication 228 (Symposium at Boulder, CO 1995 - Biogeochemistry of Seasonally Snow-Covered Catchments), 379-386.

Funk, M. and H. Röthlisberger. 1989. Forecasting the effects of a planned reservoir which will partially flood the tongue of Unteraargletscher in Switzerland. Ann. Glaciol., 13, 76-81.

Funk, M., G.H. Gudmundsson and F. Hermann. 1994. Geometry of the glacier bed of the Unteraarglacier, Bernese Alps, Switzerland. Z. Gletscherkd. Glazialgeol., 30, 187-194.

Gudmundsson, G.H., A. Iken and M. Funk. 1997. Measurements of ice deformation at the confluence area of Unteraargletscher, Bernese Alps, Switzerland. J. Glaciol., 43(145), 548-556.

Gudmundsson, G.H., A. Bauder, M. Lüthi, U.H. Fischer and M. Funk. 1999. Estimating rates of basal motion and internal ice deformation from continuous tilt measurements. Ann. Glaciol., 28, 247-252.

Gudmundsson, G.H., A. Bassi, M. Vonmoos, A. Bauder, U.H. Fischer and M. Funk. 2000. High-resolution measurements of spatial and temporal variations in surface velocities of Unteraargletscher, Bernese Alps, Switzerland. Ann. Glaciol., 31, 63-68.

Hagen, J.O., B. Etzelmüller and A.M. Nuttall. 2000. Runoff and drainage pattern derived from digital elevation models, Finsterwalderbreen, Svalbard. Ann. Glaciol., 31, 147-152.

Iken, A. and M. Truffer. 1997. The relationship between subglacial water pressure and velocity of Findelengletscher, Switzerland, during its advance and retreat. J. Glaciol., 43(144), 328-338.

Iken, A., H. Röthlisberger, A. Flotron and W. Haeberli. 1983. The uplift of Unteraargletscher at the beginning of the melt season - a consequence of water storage at the bed? J. Glaciol., 29 (101), 28-47.

L+T (= Landestopographie). 1993. Digitales Höhenmodell DHM25. Wabern, Bundesamt für Landestopographie. Produktinformation.

Nienow, P., M. Sharp and I. Willis. 1998. Seasonal changes in the morphology of the subglacial drainage system, Haut Glacier d'Arolla, Switzerland. Earth Surf. Process. Landforms, 23(9), 825-843.

Quinn, P., K. Beven, P. Chevallier and O. Planchon. 1991. The prediction of hillslope flow paths for distributed hydrological modeling using digital terrain models. Hydrol. Process., 5, 59-80.

Rippin, D. and 6 others. 2003. Changes in geomety and subglacial drainage of Midre Lovénbreen, Svalbard, determined from digital elevation models. Earth Surf. Process. Landforms, 28(3), 273-298.

Schuler, T. and U.H. Fischer. 2003. Elucidating changes in the degree of tracer dispersion in a subglacial channel. Ann. Glaciol., 37, 275-280.

Schuler, T., U.H. Fischer, R. Sterr, R. Hock and G.H. Gudmundsson. 2002. Comparison of modeled water input and measured discharge prior to a release event: Unteraargletscher, Bernese Alps, Switzerland. Nord. Hydrol., 33(1), 27-46.

Schuler, T., U.H. Fischer and G.H. Gudmundsson. 2004. Diurnal variability of subglacial drainage conditions as revealed by tracer experiments. J. Geophys. Res., 109(F2), F02008. (10.1029/2003JF000082.)

Sharp, M. and 6 others. 1993. Geometry, bed topography and drainage system structure of the Haut Glacier d'Arolla, Switzerland. Earth Surf. Process. Landforms, 18(6), 557-571.

Shreve, R.L. 1972. Movement of water in glaciers. J. Glaciol., 11(62), 205-214.

Zevenbergen, L.W. and C.R. Thorne. 1987. Quantitative analysis of land surface topography. Earth Surf. Process. Landforms, 12(1), 47-56. 